\title{
Knowledge and Practice of Traditional Birth Attendants (TBAs) in Eritrea
}

\author{
Mismay Ghebrehiwet, MD, MPH, PhD; Richard H. Morrow, MD \\ ${ }^{1}$ Advisor to the Minister of Health State of Eritrea. \\ Corresponding author: Dr Mismay Ghebrehiwet, \\ email address: gmismay@yahoo.com
}

Abstract

Objective: Assess the Knowledge and Practice of Traditional Birth Attendants (TBAs) in Eritrea, in order to stimulate discussions and decisions on the role of TBAS and the way forward.

Methods: the study was a cross sectional survey undertaken using structured interviews with TBAs that was conducted to collect data on their knowledge, practice, training status and the support and supervision they get from health staff.

Findings: This study reveals that only 58 percent of traditional birth attendants in Eritrea use appropriate and sterile instruments. There is therefore an urgent need for improving the spread of the use of appropriate sterile instrumentsTraditional Birth Attendants, a practice which is important not only fot the prevention of puerperal sepsis but also for the prevention of the spread of HIV-AIDS. Over all only 36 percent of TBAs had supervisory support in the six months prior to the study.

Conclusion: The study concludes that, as long as TBAs continue to function as delivery attendants, we need to educate and encourage them to identify danger signs and to promptly refer complications

Key words: Traditional Birth Attendants (TBAS), Skilled Birth Attendants, Training, Delivery, Complications, Supervision.

\section{Introduction}

One of the strategies Ministries of Health and their partners have adopted with the aim of promoting safe motherhood since the 1980's is training unskilled traditional birth attendants (TBAs). However, the assumption that training of traditional birth attendants (TBAs) would contribute greatly to reduce maternal mortality has been disproved in recent years (World Bank, 2003). The training of traditional birth attendants (TBAs) is meant to reduce post-partum infection by encouraging cleanliness and discouraging dangerous practices. While such training may reduce these particular problems, labour and delivery will still be complicated in a certain number of cases. TBAs have neither the skills nor the equipment to treat lifethreatening complications. Without medicaleducation, supplies and equipment, these TBAs can assist at normal deliveries but cannot handle life-threatening complications (Koblinsky et al, 1999, World Bank 2003 a, World Bank 2003 b).

It was also believed that TBAs could be trained to recognize obstetric complications and refer women with complications to a nearby health facility for treatment. There are two weaknesses in this plan. First of all, the signs and symptoms of serious complications including: any bleeding during pregnancy, excessive bleeding during or after delivery; convulsions; fever, chills and foul vaginal discharge; headaches in combination with swollen hands, face and feet; labour for more than 12 hours are not difficult to recognize (Wardlaw et al, 1999; Maine et al 1999b). Every one (family decision maker including husbands, mothers, mothers in-law etc..) should be informed/educated to recognize these few danger signs, not just TBAs or pregnant women.

Although much attention has been given to training TBAs in low- and mid-income countries, the evidence on focusing on training traditional birth attendants leads to mixed results in terms of increased referrals for appropriate conditions. In urban and peri-urban areas there appears to be no impact, while there is some improvement in rural areas with low prevalence rates of the use of maternal care services (Alisjahabana et al., 1995; Bailey et al., 1994;).

The more difficult problem with training TBAs to refer women with complications is that there is often no feasible referral option. In fact, it is precisely in circumstances where medical treatment is least available that training TBAs is usually proposed as a solution.

The question now is should TBA program be phased out? In settings where women commonly give birth at home with TBAs, some researchers recommend training the TBAs to recognize lifethreatening complications and to refer women in need of emergency care to skilled providers. Other researchers/experts recommend phasing out the role of the TBA in favour of more highly skilled health care workers (Elizabeth I, et al, 2002).

This study was undertaken to assess the Knowledge and Practice of Traditional Birth Attendants (TBAs) in Eritrea, in order to stimulate discussions and decisions on the role of TBAS and the way forward.

\section{Methodology}

Structured interviews with TBAs were conducted to collect data on their knowledge, practice, training status and the support and supervision they get from health staff.

TBAs were interviewed in seven randomly selected communities (administrative areas) from each of the zones (a total of 42), that were selected for the study.

During the visit to the zonal health office, the interviewers asked the zonal health office staff for a list of all traditional birth attendants in the selected communities in the zone. If this list was not available, the names of all traditional birth attendants in the selected communities were prepared by requesting 
the staff at the time of the visit to the health facilities and the area administration officers during the community visit.

It was necessary to visit each community before conducting the interviews to meet with community leaders to explain the purpose of the visit and to make other advance arrangements, including verification and/or preparation of the list of all traditional birth attendants in the community (administrative area).

From the list of traditional birth attendants (both trained and untrained) in the selected community (administrative area), one traditional birth attendant was selected at random to be interviewed. The second traditional birth attendant selected for interview was the one who lives closest to the first and opposite to the status of training (If the first was trained the second one will be non-trained and vice versa). If all of the TBAs in the community were either all trained or non-trained, the second one would still be the one who lives closest but would be the same in training status, as there was no option. Hence, two traditional birth attendant interviews were carried out in each community.

As depicted in table 1, a total of 90 TBAs were interviewed. A total of 14 (2X7) TBAs were interviewed from each of Debub, Anseba and Southern Red Sea Zones, and 13 from Gash Barka and Southern Red Sea Zones each (one of the communities in each of these two Zones had only one TBA), and 22 TBAs were interviewed from Zoba Maakel.

Table 1: Number of TBAs interviewed, by Zoba (Zone)

\begin{tabular}{|l|l|l|l|l|l|l|l|}
\hline $\begin{array}{l}\text { Zoba } \\
\text { (Zone) }\end{array}$ & $\begin{array}{l}\text { Maa } \\
\text { kel }\end{array}$ & $\begin{array}{l}\text { De } \\
\text { bub }\end{array}$ & $\begin{array}{l}\text { Ans } \\
\text { eba }\end{array}$ & $\begin{array}{l}\text { Gash } \\
\text { Barka }\end{array}$ & NRS & SRS & Total \\
\hline $\begin{array}{l}\text { No. of } \\
\text { TBAs }\end{array}$ & 22 & 14 & 14 & 13 & 13 & 14 & 90 \\
\hline
\end{tabular}

\section{Results}

Majority (73 percent) of deliveries in Eritrea occur at home. Although limited, some assessment was undertaken to examine the knowledge and practices of TBAs in managing a normal delivery and identifying complicated delivery for early referral. The study also assessed the training and supervisory support they get from the health staff. Findings on practices of traditional birth Attendants pertaining cord care and herbs usage, training and skills maintenance, knowledge of TBAs on obstetric complications, advice or information provided to mothers by TBAs is presented in this section.

\section{Cord care and Herb usage among TBAs}

In this study use of razor blade or scissors for cord cut, was considered as appropriate. A new (not previously opened) razor blade or properly boiled scissors and boiled used razorblade were considered as sterile. A previously opened or used razor blade or scissors, if not boiled were considered non sterile.

Tables 2 and 3 summarize findings of practices of traditional birth Attendants pertaining to cord care and herbs usage respectively. Most Traditional birth attendants use either razor blade or scissors for cord cut, which were considered as appropriate. As indicated in table 2, fifty eight percent of the traditional birth attendants use appropriate and sterile instrument, while one third of the traditional birth attendants use appropriate but non sterile instruments. About Sixty four percent of the trained TBAs and 51 percent of the untrained TBAs use appropriate and sterile instruments.

\begin{tabular}{|l|c|c|c|}
\hline \multicolumn{3}{|c|}{ Table 2: Cord care by TBAs } \\
\hline $\begin{array}{l}\text { Instrument used for } \\
\text { cutting cord }\end{array}$ & \multicolumn{1}{l}{ Traditional Birth Attendant } \\
\hline & Untrained & Trained & Total \\
\hline $\begin{array}{l}\text { Appropriate sterile } \\
\text { instrument }\end{array}$ & $51.2 \%$ & $63.8 \%$ & $57.8 \%$ \\
\hline $\begin{array}{l}\text { Appropriate instrument, } \\
\text { but not sterile }\end{array}$ & $37.2 \%$ & $29.8 \%$ & $33.3 \%$ \\
\hline $\begin{array}{l}\text { Traditional materials } \\
\text { (Inappropriate materials) }\end{array}$ & $4.7 \%$ & $4.3 \%$ & $4.4 \%$ \\
\hline Other & $7.0 \%$ & $2.1 \%$ & $4.4 \%$ \\
\hline Treatment of cord & $72.1 \%$ & $78.7 \%$ & $75.6 \%$ \\
\hline Nothing & $4.7 \%$ & $2.1 \%$ & $3.3 \%$ \\
\hline Ash & $2.3 \%$ & $2.1 \%$ & $2.2 \%$ \\
\hline Herbs or flowers & $0.0 \%$ & $10.6 \%$ & $5.6 \%$ \\
\hline Alcohol & $20.9 \%$ & $6.4 \%$ & $13.3 \%$ \\
\hline Other & 43 & 47 & 90 \\
\hline $\begin{array}{l}\text { Number of TBAs } \\
\text { sampled (n) }\end{array}$ & & & \\
\hline
\end{tabular}

Table 3: Herb usage among TBAs

\begin{tabular}{|l||l|l|l|}
\hline \multirow{2}{*}{ Herb usage } & \multicolumn{3}{|c|}{ Traditional Birth Attendant } \\
\cline { 2 - 4 } & Untrained & Trained & Total \\
\hline Never use herbs & $60.5 \%$ & $83.0 \%$ & $72.2 \%$ \\
\hline Use: for fever & $9.3 \%$ & $0.0 \%$ & $4.4 \%$ \\
\hline $\begin{array}{l}\text { For treatment of } \\
\text { obstructed labor }\end{array}$ & $0.0 \%$ & $2.1 \%$ & $1.1 \%$ \\
\hline at delivery & $7.0 \%$ & $2.1 \%$ & $4.4 \%$ \\
\hline $\begin{array}{l}\text { For treatment of } \\
\text { bleeding }\end{array}$ & $7.0 \%$ & $4.3 \%$ & $5.6 \%$ \\
\hline $\begin{array}{l}\text { For stimulation of } \\
\text { contractions }\end{array}$ & $9.3 \%$ & $2.1 \%$ & $5.6 \%$ \\
\hline to avoid abortion & $2.3 \%$ & $0.0 \%$ & $1.1 \%$ \\
\hline to expel placenta & $7.0 \%$ & $0.0 \%$ & $3.3 \%$ \\
\hline \multicolumn{1}{|c}{ Other } & $18.6 \%$ & $12.8 \%$ & $15.6 \%$ \\
\hline $\begin{array}{l}\text { Number of TBAs } \\
\text { sampled (n) }\end{array}$ & 43 & 47 & 90 \\
\hline
\end{tabular}

Both tables 2 and 3 depict that use of herbs or ash, as a treatment of cord ( 2 percent) or for other purposes is rare among both trained and non-trained TBAs. Over all 72 percent of the TBAs never use herbs. As depicted in table 14.2 the proportion of TBAs who never use herbs is significantly higher among the trained TBAs ( 83 percent) than among the untrained TBAs (61 percent). Training and skills maintenance 


\begin{tabular}{|l|l|l|l|l|l|l|l|l|}
\hline \multicolumn{2}{|c|}{ Table 4 Last time TBA received training, by Zone } \\
\hline \multirow{2}{*}{ Last training } & \multicolumn{3}{|c|}{ Zoba (Gash Barka) } \\
\cline { 2 - 10 } & Maakel & Debub & Anseba & $\begin{array}{l}\text { Gash } \\
\text { Barka }\end{array}$ & NRS & SRS & Total & Cumulative $\%$ \\
\hline In the past week & $4.5 \%$ & $0.0 \%$ & $0.0 \%$ & $0.0 \%$ & $7.7 \%$ & $0.0 \%$ & $2.2 \%$ & $2.2 \%$ \\
\hline In the past month & $4.5 \%$ & $0.0 \%$ & $0.0 \%$ & $0.0 \%$ & $0.0 \%$ & $0.0 \%$ & $1.1 \%$ & $3.3 \%$ \\
\hline In the past 6 months & $9.1 \%$ & $7.1 \%$ & $14.3 \%$ & $7.7 \%$ & $7.7 \%$ & $14.3 \%$ & $10.0 \%$ & $13.3 \%$ \\
\hline In the past year & $40.9 \%$ & $35.7 \%$ & $14.3 \%$ & $23.1 \%$ & $7.7 \%$ & $35.7 \%$ & $27.8 \%$ & $41.1 \%$ \\
\hline In the past 5 years & $4.5 \%$ & $14.3 \%$ & $7.1 \%$ & $15.4 \%$ & $15.4 \%$ & $14.3 \%$ & $11.1 \%$ & $52.2 \%$ \\
\hline Never & $36.4 \%$ & $42.9 \%$ & $64.3 \%$ & $53.8 \%$ & $61.5 \%$ & $35.7 \%$ & $47.8 \%$ & $100.0 \%$ \\
\hline Number of TBAs sampled (n) & 22 & 14 & 14 & 13 & 13 & 14 & 90 & - \\
\hline
\end{tabular}

Table 5: Last time TBAs attended delivery

\begin{tabular}{|l|l|l|l|c|}
\hline \multirow{2}{*}{ Last delivery } & \multicolumn{4}{l}{ Traditional birth attendants } \\
\cline { 2 - 5 } & Untrained & Trained & Total & Cumulative $\%$ \\
\hline In the past week & $18.6 \%$ & $27.7 \%$ & $23.3 \%$ & $23.3 \%$ \\
\hline In the past month & $30.2 \%$ & $38.3 \%$ & $34.4 \%$ & $57.7 \%$ \\
\hline In the past 6 mo. & $30.2 \%$ & $21.3 \%$ & $25.6 \%$ & $83.3 \%$ \\
\hline In the past year & $16.3 \%$ & $12.8 \%$ & $14.4 \%$ & $97.7 \%$ \\
\hline In the past 5 years & $4.7 \%$ & $0.0 \%$ & $2.2 \%$ & $99.9 \%$ \\
\hline Never & $0.0 \%$ & $0.0 \%$ & $0.0 \%$ & $99.9 \%$ \\
\hline Number of TBAs sampled $(\mathrm{n})$ & 43 & 47 & 90 & - \\
\hline
\end{tabular}

Table 4 reveals that only 13 percent of the traditional birth attendants received training in the past 6 months, while a cumulative of 41 percent received training in one year time prior to the study, and a cumulative 52 percent in the past five years, the remaining 48 percent never received training.

In order to maintain the skills of the TBAs up to standard (provided they are supervised by conventionally trained health staffi.e. nurses/midwives) it is important that they regularly practice assisting mothers during their delivery. Tables 5 depicts the last time the TBAs attended delivery.

The table reveals that 68 percent of the TBAs attended their last delivery within the month prior to the study and majority (83 percent) within 6 months, only 2 percent did not attend any delivery for one to five years (all of them among the untrained ones). There was no TBA who has never attended a delivery. The findings in table 9.4 suggest that the trained TBAs tend to have more recent experience of delivery as compared with the untrained TBAs.

Table 6: Timing of facility postpartum visits, as recommended by TBA

\begin{tabular}{|c|c|c|c|c|}
\hline \multirow{2}{*}{$\begin{array}{l}\text { Timing of } \\
\text { recommended } \\
\text { postpartum } \\
\text { visit }\end{array}$} & \multicolumn{4}{|c|}{$\begin{array}{l}\text { Traditional Birth Attendants } \\
\text { (TBAs) }\end{array}$} \\
\hline & $\begin{array}{l}\text { Untra } \\
\text { ined }\end{array}$ & $\begin{array}{l}\text { Trai } \\
\text { ned }\end{array}$ & Total & $\begin{array}{l}\text { Cumula } \\
\text { tive } \%\end{array}$ \\
\hline Immediately & $4.7 \%$ & $0.0 \%$ & $2.2 \%$ & $2.2 \%$ \\
\hline During first week & $2.3 \%$ & $6.4 \%$ & $4.4 \%$ & $6.6 \%$ \\
\hline $\begin{array}{l}\text { During first } 6 \\
\text { weeks }\end{array}$ & $4.7 \%$ & $10.6 \%$ & $7.8 \%$ & $14.4 \%$ \\
\hline $\begin{array}{l}\text { If motheris ill or } \\
\text { has problem }\end{array}$ & $11.6 \%$ & $19.1 \%$ & $15.6 \%$ & $30.0 \%$ \\
\hline Other & $0.0 \%$ & $2.1 \%$ & $1.1 \%$ & $31.1 \%$ \\
\hline $\begin{array}{l}\text { Never or does } \\
\text { not refer }\end{array}$ & $76.7 \%$ & $59.6 \%$ & $67.8 \%$ & $98.9 \%$ \\
\hline $\begin{array}{l}\text { Number of TBAs } \\
\text { sampled (n) }\end{array}$ & 43 & 47 & 90 & - \\
\hline
\end{tabular}


Table 6 reveals whether Traditional birth attendants recommend postpartum visit to a health facility for those deliveries they attended and when they do, the timing they recommended for the visit. Findings indicates only a cumulative of 14 percent routinely advise mothers to visit a health facility for postpartum check up with in the first 6 weeks after delivery. The remaining majority (85 percent) do not advise mothers to go for a postpartum checkup routinely. Sixteen percent advise mothers to go to a health facility for a postpartum check up only if they encountered a problem during delivery or if the mother is ill, while two third of the TBAs never advise mothers to go to health facility for a post partum check up. The proportion of TBAs who never advise or refer mothers to a health facility for a postpartum check up is higher among the untrained TBAs (77 percent) than the trained TBAs (60 percent)

\section{Knowledge of TBAs on obstetric complications}

The major role of TBA in relation to obstetric complications is early recognition and referral. Table 7 present knowledge of Traditional Birth Attendants of warning signs and symptoms of pregnancy, delivery and perperium, which prompt referral. When the TBAs were asked what warning signs would prompt them to refer their clients, only 10 percent mentioned any previous bad obstetric history including previous caesarian section, previous stillbirth etc., only 19 percent mentioned cessation of fetal movement or when baby doesn't move, only 21 percent mentioned a sign related with sepsis e.g. foul vaginal discharge or low abdominal pain. Although three fourth mentioned hemorrhage or bleeding less than a quarter included or specifically mentioned light bleeding or spotting.

As depicted in table 7 the trained TBAs, were better than the untrained ones in recalling warning signs that prompt them to refer. As seen in the qualitative information of the case control component of this study (part II), in some of the instances of complication, the TBA try to treat the complications herself in other instances they do not recognize the symptoms as a problem and wait until it is too late.

It is important that the TBAs (as well as the mother and her families) know and identify complications that require referral early, so that the referral process begins. The knowledge on the danger signs during pregnancy and delivery was generally low for both trained and untrained TBAs.

\begin{tabular}{|l|l|l|l|}
\hline \multicolumn{3}{|l|}{$\begin{array}{l}\text { Table 7: Knowledge by TBAs of warning signs, } \\
\text { which would prompt referral }\end{array}$} \\
\hline $\begin{array}{l}\text { Warning } \\
\text { signs recalled }\end{array}$ & \multicolumn{3}{|l|}{ Traditional Birth Attendant } \\
\cline { 2 - 4 } & $\begin{array}{l}\text { Un } \\
\text { trained }\end{array}$ & Trained & Total \\
\hline $\begin{array}{l}\text { Previous bad } \\
\text { obstetric history or } \\
\text { abdominal scars or } \\
\text { previous stillbirth }\end{array}$ & $9.3 \%$ & $10.6 \%$ & $10.0 \%$ \\
\hline
\end{tabular}

\begin{tabular}{|l|l|l|l|}
\hline $\begin{array}{l}\text { Hypertension } \\
\text { or headache or } \\
\text { swelling or fits }\end{array}$ & $27.9 \%$ & $48.9 \%$ & $38.9 \%$ \\
\hline $\begin{array}{l}\text { Anemia or pallor } \\
\text { or fatigue or } \\
\text { breathlessness }\end{array}$ & $37.2 \%$ & $57.4 \%$ & $47.8 \%$ \\
\hline $\begin{array}{l}\text { Cessation of fetal } \\
\text { movement or baby } \\
\text { does not move }\end{array}$ & $14.0 \%$ & $23.4 \%$ & $18.9 \%$ \\
\hline $\begin{array}{l}\text { Abnormal lie or } \\
\text { position of fetus }\end{array}$ & $46.5 \%$ & $57.4 \%$ & $52.2 \%$ \\
\hline $\begin{array}{l}\text { Sepsis or foul } \\
\text { smelling discharge } \\
\text { or postpartum } \\
\text { abdominal pain }\end{array}$ & $23.3 \%$ & $19.1 \%$ & $21.1 \%$ \\
\hline $\begin{array}{l}\text { Light bleeding or } \\
\text { spotting }\end{array}$ & $25.6 \%$ & $21.3 \%$ & $23.3 \%$ \\
\hline $\begin{array}{l}\text { Hemorrhage or } \\
\text { heavy bleeding }\end{array}$ & $67.4 \%$ & $85.1 \%$ & $76.7 \%$ \\
\hline $\begin{array}{l}\text { Multiplepregnancy } \\
\text { or large abdomen }\end{array}$ & $2.3 \%$ & $19.1 \%$ & $11.1 \%$ \\
\hline $\begin{array}{l}\text { Obstructed or } \\
\text { prolonged labor or } \\
\text { "sun set two times" }\end{array}$ & $55.8 \%$ & $46.8 \%$ & $51.1 \%$ \\
\hline $\begin{array}{l}\text { Number of TBAs } \\
\text { sampled (n) }\end{array}$ & 43 & 47 & 90 \\
\hline
\end{tabular}

Table 8: Last time TBA saw a woman with complications of abortion, by Zone

\begin{tabular}{|c|c|c|c|c|c|c|c|}
\hline \multirow{2}{*}{$\begin{array}{l}\text { Last } \\
\text { incomplete } \\
\text { abortion } \\
\text { seen by } \\
\text { TBA }\end{array}$} & \multicolumn{7}{|c|}{ Zoba (Zone) } \\
\hline & $\begin{array}{l}\text { Maa } \\
\text { kel }\end{array}$ & $\begin{array}{l}\text { De } \\
\text { bub }\end{array}$ & $\begin{array}{l}\text { Ans } \\
\text { eba }\end{array}$ & $\begin{array}{l}\text { Gash } \\
\text { Barka }\end{array}$ & NRS & SRS & Total \\
\hline $\begin{array}{l}\text { In the past } \\
\text { week }\end{array}$ & $0.0 \%$ & $7.1 \%$ & $7.1 \%$ & $0.0 \%$ & $0.0 \%$ & $0.0 \%$ & $2.2 \%$ \\
\hline $\begin{array}{l}\text { In the past } \\
\text { month }\end{array}$ & $18.2 \%$ & $28.6 \%$ & $7.1 \%$ & $0.0 \%$ & $7.7 \%$ & $7.1 \%$ & $12.2 \%$ \\
\hline $\begin{array}{l}\text { In the past } \\
6 \text { months }\end{array}$ & $4.5 \%$ & $21.4 \%$ & $14.3 \%$ & $7.7 \%$ & $\begin{array}{l}0.0 \\
\%\end{array}$ & $7.1 \%$ & $8.9 \%$ \\
\hline $\begin{array}{l}\text { In the past } \\
5 \text { years }\end{array}$ & $4.5 \%$ & $0.0 \%$ & $14.3 \%$ & $0.0 \%$ & $7.7 \%$ & $7.1 \%$ & $5.6 \%$ \\
\hline $\begin{array}{l}5 \text { years ago } \\
\text { or longer }\end{array}$ & $13.6 \%$ & $0.0 \%$ & $0.0 \%$ & 7.7\% & $0.0 \%$ & 7.1\% & $5.6 \%$ \\
\hline Never & $36.4 \%$ & $28.6 \%$ & $50.0 \%$ & $84.6 \%$ & $69.2 \%$ & $50.0 \%$ & $51.1 \%$ \\
\hline $\begin{array}{l}\text { Number } \\
\text { of TBAs } \\
\text { sampled } \\
\text { (n) }\end{array}$ & 22 & 14 & 14 & 13 & 13 & 14 & 90 \\
\hline
\end{tabular}


TBAs were asked whether women come to them for assistance with the complications of abortion. As revealed in table 8 , half of the TBAs interviewed said women never come to them for complications of abortion. About one third of the TBAs had seen at least one case with complications of abortion ranging from within a week to a year. The TBAs that said have seen a case said they referred such cases to the health facilities. The fact that about one third of the TBAs have seen at least one case of abortion complication within the last year shows that clearly TBAs could have a role to play in recognition of symptoms of abortion complications and in their prompt referral for treatment. and personal hygiene (50 percent).

Over all the trained TBAs seem to provide more information to their clients than the untrained ones. 17 percent of the trained TBAs said they provide information or advice mothers to go to health facility for Child spacing or family planning, while none of the untrained TBAs said so. All TBAs (trained or untrained) in Zobas Anseba and southern Red Sea do not provide any information on family planning to their clients. Information on cord care is provided to clients only by some TBAs in Zoba Maakel (18.2 percent).

Table 9 : Educational messages and advice given after delivery to clients by TBAs

\begin{tabular}{|l|l|l|l|}
\hline Advice or information provided to mothers & \multicolumn{3}{l|}{ Traditional birth attendant } \\
\cline { 2 - 4 } & Untrained & Trained & Total \\
\hline Child spacing or family planning & $0.0 \%$ & $17.0 \%$ & $8.9 \%$ \\
\hline Early breast-feeding & $51.2 \%$ & $66.0 \%$ & $58.9 \%$ \\
\hline Information on postpartum complications & $9.3 \%$ & $14.9 \%$ & $12.2 \%$ \\
\hline Cord care & $4.7 \%$ & $4.3 \%$ & $4.4 \%$ \\
\hline Nutrition for mother & $62.8 \%$ & $68.1 \%$ & $65.6 \%$ \\
\hline Immunization & $11.6 \%$ & $25.5 \%$ & $18.9 \%$ \\
\hline Personal hygiene & $48.8 \%$ & $51.1 \%$ & $50.0 \%$ \\
\hline Number of TBAs sampled $(\mathrm{n})$ & 43 & 47 & 90 \\
\hline
\end{tabular}

Table 10: Educational messages and advice given after delivery to clients by TBAs

\begin{tabular}{|l|l|l|l|l|l|l|l|}
\hline \multirow{2}{*}{$\begin{array}{l}\text { Advice or information provided to } \\
\text { mothers }\end{array}$} & \multicolumn{4}{l}{ Zoba (Zone) } \\
\cline { 2 - 8 } & Maakel & Debub & Anseba & Gash Barka & NRS & SRS & Total \\
\hline Child spacing or family planning & $13.6 \%$ & $14.3 \%$ & $0.0 \%$ & $15.4 \%$ & $7.7 \%$ & $0.0 \%$ & $8.9 \%$ \\
\hline Early breast-feeding & $59.1 \%$ & $50.0 \%$ & $57.1 \%$ & $46.2 \%$ & $61.5 \%$ & $78.6 \%$ & $58.9 \%$ \\
\hline Information on postpartum complications & $13.6 \%$ & $7.1 \%$ & $14.3 \%$ & $15.4 \%$ & $7.7 \%$ & $14.3 \%$ & $12.2 \%$ \\
\hline Cord care & $18.2 \%$ & $0.0 \%$ & $0.0 \%$ & $0.0 \%$ & $0.0 \%$ & $0.0 \%$ & $4.4 \%$ \\
\hline Nutrition for mother & $50.0 \%$ & $64.3 \%$ & $78.6 \%$ & $69.2 \%$ & $61.5 \%$ & $78.6 \%$ & $65.6 \%$ \\
\hline Immunization & $22.7 \%$ & $7.1 \%$ & $21.4 \%$ & $23.1 \%$ & $30.8 \%$ & $7.1 \%$ & $18.9 \%$ \\
\hline Personal hygiene & $54.5 \%$ & $57.1 \%$ & $50.0 \%$ & $53.8 \%$ & $30.8 \%$ & $50.0 \%$ & $50.0 \%$ \\
\hline Number of TBAs sampled $(\mathrm{n})$ & 22 & 14 & 14 & 13 & 13 & 14 & 90 \\
\hline
\end{tabular}

Advice or information provided to mothers by TBAs

Tables 9 and 10 present Educational messages and advice given to their clients after delivery by TBA status of training and by Zone respectively. As depicted in table 9.8, the most common advice provided to clients after delivery by the TBAs were on: - nutrition for mother (66 percent), early breast-feeding (59 percent)

\section{Supervisory support provided to TBAs}

As depicted in table 11, the majority (57 percent) of the TBAs never got any supervisory support from the health facilities. Only 36 percent got a supervisory support in the six months prior to the study. Provision of supervisory support to TBAs is weak in all Zones. 
Table 11: Last time TBAs received supervisory support

\begin{tabular}{|c|c|c|c|c|c|c|c|c|}
\hline \multirow[t]{2}{*}{ Last } & \multicolumn{8}{|c|}{ Zoba (Zone) } \\
\hline & Maakel & Debub & Anseba & GashBarka & NRS & SRS & Total & Cumulative \% \\
\hline
\end{tabular}

Actual supervision reported by staff

\begin{tabular}{|l|l|l|l|l|l|l|l|l|}
\hline In the past week & $18.2 \%$ & $7.1 \%$ & $0.0 \%$ & $7.7 \%$ & $15.4 \%$ & $14.3 \%$ & $11.1 \%$ & $11.1 \%$ \\
\hline In the past month & $22.7 \%$ & $7.1 \%$ & $0.0 \%$ & $15.4 \%$ & $7.7 \%$ & $7.1 \%$ & $11.1 \%$ & $22.2 \%$ \\
\hline In the past 6 months & $4.5 \%$ & $35.7 \%$ & $21.4 \%$ & $15.4 \%$ & $0.0 \%$ & $7.1 \%$ & $13.3 \%$ & $35.5 \%$ \\
\hline In the past year & $4.5 \%$ & $0.0 \%$ & $7.1 \%$ & $0.0 \%$ & $7.7 \%$ & $0.0 \%$ & $3.3 \%$ & $38.8 \%$ \\
\hline In the past 5 years & $0.0 \%$ & $0.0 \%$ & $7.1 \%$ & $0.0 \%$ & $0.0 \%$ & $7.1 \%$ & $2.2 \%$ & $41.0 \%$ \\
\hline Never & $50.0 \%$ & $50.0 \%$ & $57.1 \%$ & $61.5 \%$ & $69.2 \%$ & $57.1 \%$ & $56.7 \%$ & $97.7 \%$ \\
\hline $\begin{array}{l}\text { Number of TBAs } \\
\text { sampled }(\mathrm{n})\end{array}$ & 22 & 14 & 14 & 13 & 13 & 14 & 90 & - \\
\hline
\end{tabular}

\section{Discussion}

Only very low proportions of deliveries (one third of child immunization attendants) delivered in health facility and were attended by qualified health workers. There is urgent need of improving proportion of deliveries attended by skilled attendants, as studies have shown the need for every delivery to be attended by a skilled health worker. Until such a time when most or all deliveries are attended by trained health workers, it is of particular importance for pregnant women, families and all persons attending deliveries to be aware of what they can do to promote and protect the health of pregnant women and to ensure early referral when problems arise.

The review of the available literature and information indicated that the earlier belief that the training of TBAs would contribute greatly to reductions in maternal mortality has been disproved in recent years.

However, as long as TBAs continue to attend a large proportion of home deliveries, training courses can be effective in upgrading their knowledge. Training of TBAs should however be clearly seen as a way of bridging the gap until all women and children have access to acceptable, professional health care services, which the Government should plan for.

This study reveals that only 58 percent of the traditional birth attendants use an appropriate and sterile instrument. Hence there is urgent need of improving the percentage of Traditional Birth Attendants that use appropriate sterile instruments, which is important not only to prevent puerperal sepsis but also in relation to prevention of spread of HIV-AIDS.

Early detection and referral of obstetric complications should be emphasized during any TBA training. Currently the majority of TBAs could not recall warning sings that would prompt referral. (many wait until it is too late before they actually refer)

TBA training could not be effective without continuous supervisory support; hence the urgent need for improving on the number of TBAs (trained or untrained) who are provided with supervisory support.
In total, only 36 percent of TBAs got a supervisory support in the six months prior to the study.

\section{Conclusions}

1. Educate and encourage TBAs and peripheral health workers to identify danger signs and to promptly refer complications (As long as TBAs continue to function as delivery attendants).

2. Learn lessons from the TBAs approach to mothers and undertake formative research to accordingly improve interpersonal communication skills of health care providers.

3. Initiate long-term plans aimed at eventually ensuring attendance of every delivery (at home or in health facility) by a skilled birth attendant.

\section{References}

Alisjahabana et al., 1995;

Bailey et al., 1994;

Elizabeth I, Ransom and Nancy V. Yinger, Making Mother hood Safer, Overcoming Obstacles on the Pathway to are; Population Reference Bureau, February 2002.

Koblinsky M. Safe Motherhood Indicators - Lessons learned in measuring progress. In: Mother Care Matters May 1999 Vol.8(1).

WardlawT, Maine D. Process Indicators for Maternal Mortality Programmes: In Reproductive Health Matters (eds M Berer \& TKS Ravindram), 1999 Blackwell, Oxford, pp 24-30.

World Bank, Pathaman I et al eds., Investing in Maternal health, Learning from Malaysia and Sri Lanka, Human Development Network, Health, Nutrition, and Population Series. The World Bank, Washington D.C. 2003 (a).

World Bank, Koblinsky M. Editor, Reducing Materna Mortality. Learning from Bolivia, China, Egypt, Honduras, Indonesia, Jamaica, and Zimbabwe. Human Development Network, Health, Nutrition, and Population Series. The World Bank, Washington D.C. 2003 (b).

World Health organization. Reduction of maternal mortality. A joint WHO/UNFPA/World Bank publication; Geneva: World Health Organization; 1999. 